\title{
BECOMING A COSMOPOLITAN LAWYER
}

\author{
John Flood* \& Peter D. Lederer** \\ INTRODUCTION
}

The practice of law has become increasingly globalized over the last forty years. Law firms, although national in origin, now depict themselves as global, international, or regional. ${ }^{1}$ Most of the lawyers practicing in these firms are educated and trained in one jurisdiction but work globally. True, the market for LL.M. degrees has prompted inter-jurisdictional exchanges in legal education, so we find increasing numbers of law students educated in civil law systems migrating to common law jurisdictions. $^{2}$ But as a whole, the legal profession has come to globalization gradually, led there by client demand rather than an inherent desire to supply global services. If we compare the spread of the law practice to that of accounting and management consulting, we can see that law has remained a cottage industry to a large extent. ${ }^{3}$

Talking about the globalization of law ordinarily means examining structures, organizations, developments in professionalism, cultural modes of production, educational systems, and the like. If we focus this examination on the people who populate the legal industry, a different view emerges. This is similar to the anthropological distinction between etic and emic perspectives. ${ }^{4}$ Globalization focuses on the etic, the view from

* Professor of Law and Sociology, University of Westminster School of Law. Both authors are grateful to the University of Miami School of Law for its support of their research.

** Visiting Practitioner in Residence, University of Miami School of Law.

1. One only has to peruse their websites to see the claims they make. For instance, Clifford Chance says, "[W]e pride ourselves on combining the highest global standards with local expertise.” See About Us, ClifFORD CHANCE, http://www.cliffordchance.com/about_ us.html (last visited Apr. 21, 2012).

2. See generally Carole Silver, The Variable Value of U.S. Legal Education in the Global Legal Services Market, 24 GeO. J. Legal Ethics 1 (2011) (noting that civil law students study law in the United States to learn English and to network); John Flood, Legal Education in the Global Context: Challenges from Globalization, Technology and Changes in Government Regulation, LEGAL SERVICES BOARD (2011), http://www.legalservicesboard. org.uk/news_publications/latest_news/pdf/lsb_legal_education_report_flood.pdf (discussing the flow of graduate law students throughout the world).

3. John Flood, Lawyers as Sanctifiers: The Role of Elite Law Firms in International Business Transactions, 14 InD. J. GLOBAL LEGAL STUD. 35, 49-50 (2007).

4. The distinctions between emic and etic can be traced to the nineteenth century, but they are crystallized in Kenneth L. PiKe, LANGUAGe in Relation to a Unified TheORY of the Structure of Human Behavior (2d ed. 1967) and Marvin Harris, Cultural MATERIAlism: The Struggle for a SCIEnCE of Culture (1979). See also ThOMAS N. Headland, Kenneth L. Pike \& Marvin Harris, Emics and Etics: The Insider/Outsider DEBATE (1990). 
outside. In this Article, we argue that to speak of becoming a cosmopolitan lawyer requires the emic perspective, that from the interior. The emic view is essential to understanding modern developments in legal practice and lawyering because it gives a voice to modes of thinking and thus permits us to see inside what we are studying. ${ }^{5}$

There are different ways of taking the emic approach. One is the use of ethnography or participant observation, which opens up everyday life to view, but that is useful primarily to learn about the present states of action and structures. ${ }^{6}$ What if we want to go back in time to discern the origins and developments of actions and structures? This is where strategies such as oral history come into play. Oral history is emic, intensive, and provides a plenitude of data for analysis. This is the approach we adopt in this Article.

We focus on the process of becoming a cosmopolitan lawyer. We consider this important because today's lawyers must be cosmopolitan if they are to function in a highly interrelated and globalized world. Parochialism becomes unsustainable in a modern world where professions generally have become more globalized. Cosmopolitanism is important because while professional associations such as partnerships have been a feature of western business life, they are not universal structures. Indeed, as professions have been transported to Asia and elsewhere, they have undergone transformations. ${ }^{7}$

Professions have traditionally had a connection to the wider world. Cosmopolitanism embraces this connection through its moral commitment to the universal human community. This commitment is apparent in the early history of cosmopolitanism. ${ }^{8}$ Kwame Anthony Appiah traces the term cosmopolitanism back to

the Cynics of the fourth century BC, who first coined the expression cosmopolitan, "citizen of the cosmos." The formulation was meant to be paradoxical, and reflected the general Cynic skepticism toward custom and tradition. A citizen ... . belonged to a particular polis, a city to which he or she owed loyalty. The cosmos referred to the world, not in the sense

5. Consider the example of a London-based Clifford Chance lawyer, in charge of the acquisition of an African mobile telephone company, who received a Dutch law degree and began working in the New York office. Using an emic approach, we can learn that the national origin of his education did not matter because his most useful technical knowledge was his proficiency with the law firm's own documents. See generally John Flood, Transnational Lawyering: Clients, Ethics and Regulation, in LAWYERS IN PRACTICE: Ethical Decision Making in ConteXt 176 (Lynn Mather \& Leslie Levin eds., 2012).

6. Ethnography is "a commitment to the first-hand experience and exploration of a particular social or cultural setting on the basis of (though not exclusively by) participant observation. Observation and participation (according to circumstance and the analytic purpose at hand) remain the characteristic feature of the ethnographic approach.” Editorial Introduction to HANDBOOK OF ETHNOGRAPHY 4-5 (Paul Atkinson et al. eds., 2007 ed.).

7. See generally Sida Liu, Globalization as Boundary-Blurring: International and Local Law Firms in China's Corporate Law Market, 42 LAW \& Soc’y REV. 771 (2008) (discussing how Chinese lawyers have adapted the western corporate law firm model to local conditions).

8. See Gerard Delanty, The Cosmopolitan Imagination: Critical Cosmopolitanism and Social Theory, 57 BRIT. J. SOC. 25, 28 (2006). 
of the earth, but in the sense of the universe. Talk of cosmopolitanism originally signaled, then, a rejection of the conventional view that every civilized person belonged to a community among communities. ${ }^{9}$

Stoic cosmopolitanism was influential, contributing to Alexander the Great's conquering drive eastwards and the later rise of the Roman Empire. ${ }^{10}$ It also found a place in the Enlightenment and in the birth of the United States, by advocating republican principles and a form of universal citizenry. ${ }^{11}$

Modern cosmopolitanism, according to David Held, "recognizes each person as an autonomous moral agent entitled to equal dignity and consideration."12 It is founded on eight principles: (1) equal worth and dignity; (2) active agency; (3) personal responsibility and accountability; (4) consent; (5) collective decision making about public matters through voting procedures; (6) inclusiveness and subsidiarity; (7) avoidance of serious harm; and (8) sustainability. ${ }^{13}$ These principles are articulated through conversation, which "helps people get used to one another." 14 Cross-cultural conversations do not require universals but only something in common. ${ }^{15}$ Because "law talk" is something lawyers have in common regardless of which legal system they were trained in, and the large global law firm represents the maturation of "law talk," this Article will focus on this form of cross-cultural conversation.

The subject of this Article is a person who embodies the intrinsic and institutional aspects of cosmopolitanism and globalization. With respect to globalization, we are primarily concerned with the changes that have occurred since the end of the Second World War. These include the rise of the welfare state, the burgeoning of international institutions such as the United Nations, the World Bank, and the International Monetary Fund, along with non-governmental organizations (NGOs) and state-parallel organizations, such as the Organisation for Economic Co-operation and Development (OECD), the reinvigorated Bank for International Settlements, and the international finance group G7. During this period,

9. Kwame Anthony Appiah, Cosmopolitanism: Ethics in a World of Strangers, at xiv (2006).

10. See John Moles, The Cynics, in The Cambridge History of GreeK and Roman Political Thought 415, 415-34 (Christopher Rowe \& Malcolm Schofield eds., 2000).

11. See generally ThOMAs J. SCHLERETH, The COSMOPOLITAN IDEAL IN ENLIGHTENMENT Thought: ITs Form AND FunCtion in the IDEAS of Franklin, Hume, AND Voltaire, 1694-1790, at 7, 34 (1977) (discussing how cosmopolitan thought informed the Enlightenment ideal and was imported into American thought).

12. David Held, Cosmopolitanism: IdeAls AND Realities 15 (2010).

13. See id. at 69.

14. APPIAH, supra note 9 , at 85.

15. Jenny Onyx et al., Scaling Up Connections: Everyday Cosmopolitanism, Complexity Theory \& Social Capital, 3 Cosmopolitan CIV. Soc’ys J. 47, 49 (2011). Furthermore, Ulrich Beck describes "[c]osmopolitan tolerance" as "neither defensive nor passive, but instead active: it means opening oneself up to the world of the Other, perceiving difference as an enrichment, regarding and treating the Other as fundamentally equal. Expressed theoretically: either-or logic is replaced by both-and logic.” Ulrich Beck, A New Cosmopolitanism Is in the Air (Nov. 2007), available at http://www.signandsight.com/ service/1603.html (Ian Pepper trans.). 
business, commerce, and finance looked outward and sought to capitalize on the beginning of a globalized world. ${ }^{16}$ This new orientation created interlocking trade relationships with the major trading regions of North America, Europe, and Asia, and helped businesses see that they could begin to profit from emerging forms of regulatory and tax arbitrage. ${ }^{17}$ Financial flows increased dramatically with twenty-four-hour markets, automated trading, and the rise of the investment bank as a dominant institution in global capital markets. New forms of borrowing such as Eurobond and Eurodollar markets emerged to challenge established financial products and provide means of avoiding domestic taxes on corporate profits. Ultimately, the social and economic philosophies of Friedrich A. Hayek and Milton Friedman propelled the neoliberal agenda to which a rising number of countries and institutions became attached. ${ }^{18}$

The effect of globalization on the legal profession is not so clear cut. For example, in 1984, the International Financial Law Review (IFLR) asked: Who or what was an international lawyer? The answer was overly technical: "A lawyer admitted in more than one jurisdiction would have good reason to claim that he is an international lawyer. . . To the practitioner [international law] is advising on transactions or litigation involving more than one jurisdiction." 19 Furthermore, the IFLR stated that international law could be practiced in two ways:

Both views accept that there is no separate body of substantive law apart from the laws of those jurisdictions in which cross-border transactions, and so litigation, take place. ... [T] [Te first—and more traditional—view is that the international lawyer is really a domestic lawyer who counsels clients from other jurisdictions with business in his own. . . The second view is that the genuine international lawyer is not the local lawyer who advises foreign clients, but the lawyer-usually from the client's own jurisdiction-who interprets the local lawyer's advice and puts that advice in the context of the client's multijurisdictional objectives, and the regulatory constraints of the client's-and the lawyer's-domestic jurisdiction. 20

The IFLR editorial unrealistically asserted, as we see it now, that " $[t]$ here is therefore no reason, on the face of it, why a firm wishing to become international ... should open foreign offices at all, provided it has a network of effective correspondents in other jurisdictions."21

16. David Held et al., Global Transformations: Politics, Economics and Culture 199-202 (1999).

17. Peter Muchlinski, Multinational Enterprises and the LaW 277-80 (1995).

18. The core elements are the rule of law, reduced states, open markets, private enterprise, and the primacy of property rights. See generally Oliver E. Williamson, THE ECONOMic Institutions of CAPITALism: Firms, Markets, RElational Contracting (1985) (arguing that the role of institutions, especially law, is crucial in economic development).

19. Editorial, Who Is the International Lawyer?, InT’L Fin. L. REV., Sept. 1984, at 2, 2.

20. Id.

21. Id. 
Since this editorial was written, the reach and spread of law firms and lawyers has encircled the globe and transformed the nature of legal practice at the transnational and international levels. There were pioneers in this process, of which Baker \& McKenzie was the most notable and distinctive. ${ }^{22}$ And though the role of law and lawyers in this development has often been forgotten, some scholars-for example, Yves Dezalay and Bryant G. Garth ${ }^{23}$-have begun to remedy this defect, while others have sought to criticize international lawyers. ${ }^{24}$

There is one other important aspect to the role of the lawyer, namely that of trusted advisor. Charles Fried first invoked the metaphor of lawyer as friend in 1976 with the question, "Can a good lawyer be a good person?" 25 The modern large law firm has a number of elements to balance: it must be responsive on a global level, strive to offer seamless service across different offices and across different levels of seniority, and seek ways of standardizing work in order to achieve cost savings in a competitive environment. Yet it must also offer an individualized service that includes the personal as well as the impersonal, and enables clients to request advice and reassurance. The lawyer-client relationship is replete with uncertainty because of the nature of legal work, and managing that uncertainty is part of the lawyer's skill set. ${ }^{26}$ In this respect, a lawyer is not just a legal technician applying knowledge to problem areas; the lawyer assumes the role of trusted advisor. This role is the hardest to describe in terms of discrete skills, as it requires not just legal proficiency, but also the traits that Fried highlighted, such as empathy, the ability to listen, and a cultural sensitivity to others.

Part of our argument is that a cosmopolitan lawyer is also a trusted advisor and that the two are intertwined by necessity, for one cannot exist without the other. The reason for this interconnectedness is that globalization increases risk and uncertainty, which is, in part, a function of the scale of business as it grows, both domestically and internationally. The global professional service provider-accountant, consultant, lawyer-must ameliorate this risk and give succor. This role is crucial to the smooth functioning of business.

22. See generally Jon R. BAuman, Pioneering a Global Vision: The StORy of BaKer \& McKenzIE (1999) (describing how the firm was shaped by Russell Baker's vision of a global law firm).

23. See generally Yves Dezalay \& Bryant G. Garth, The Internationalization of PALACE WARS: LAWYERS, ECONOMISTS, AND THE CONTEST TO TRANSFORM LATIN AMERICAN StATES (2002) (discussing the role of law and lawyers in the structuring of power and the constitution of states).

24. See generally Eric A. Posner, The Perils of Global Legalism (2009) (arguing that global legalism is an excessive faith in the efficacy of law).

25. Charles Fried, The Lawyer as Friend: The Moral Foundations of the Lawyer-Client Relation, 85 YALE L.J. 1060, 1060 (1976).

26. See generally John Flood, Doing Business: The Management of Uncertainty in Lawyers' Work, 25 LAW \& SoC'y REV. 41 (1991) (noting that the lawyer's role is to create an aura around the work of the lawyer such that the client is unaware of how it is performed). 


\section{METHOD AND DATA}

In this Article, we employ the rich method of oral history. Oral history has a long tradition on both sides of the Atlantic. In the United States, it was used to collect recordings of Native American folklore in the nineteenth century, and the Works Progress Administration used it to record accounts of survivors of the American Civil War, slavery, and life in the Great Depression. Its greatest exponent was probably Studs Terkel ${ }^{27}$-a University of Chicago-trained lawyer - who held "Conversations with America." 28 In the United Kingdom, oral history has been a major method of studying history and social science, especially the uncovering of previously hidden histories. ${ }^{29}$

Our own method adopts this approach, and it is worth prefacing our narrative to say how it came about. John Flood was a visiting professor at the University of Miami School of Law in 2008. After presenting a paper on the transnational work of lawyers, Flood met Peter Lederer, who is a practitioner in residence at that law school. Lederer's career spanned the arc of globalization and the rise of the large law firm, from the 1960s to the turn of the century. We decided that this could form the basis of a research project that could examine a number of phenomena, including ideas of career, profession, law firm life, transnationalism, legal education, and more. We therefore met twice a week with a digital recorder and talked. Our conversations or interviews lasted around two to three hours, and we have supplemented them since that initial period. Altogether we compiled almost thirty hours of transcribed interviews. In addition to the interviews, we used documents that Lederer composed during his career, a history of Baker \& McKenzie written by Jon Bauman in 1999, ${ }^{30}$ and various public documents.

It is relevant to inquire why the story of one person should be of interest. Would it not be so particular so as to have no applicability beyond its own limits? Clearly we do not think so. There is ample justification in the social science literature for deep, rich, and contextually based studies. ${ }^{31}$ Flood traces his intellectual lineage through Howard Becker, Erving Goffman, and Everett Hughes, all trained in the Chicago School ethnographic approach. Everett Hughes put it succinctly when he said

27. See generally Studs Terkel, And They All SAng: Adventures of An EClectic DisC JoCKey (2005); STUDS TERKEL, Division STREET: AMERICA (1967).

28. See generally Studs Terkel: Conversations with America, CHI. Hist. Museum, http://www.historicalvoices.org/ studs/ (last visited Apr. 21, 2012).

29. See Graham Smith, The Making of Oral History, InST. FOR HIST. REs. § 2.2, http://www.history.ac.uk/makinghistory/resources/articles/oral_history.html\#hiddenfromhist ory (last visited Apr. 21, 2012). The British Oral History Society has been a significant contributor to the making of oral histories. See OrAL HIST. SOC’y, http://www.oralhistory. org.uk/index.php (last visited Apr. 21, 2012).

30. See generally BAUMAN, supra note 22. Bauman is a former partner of Baker \& McKenzie and is now a journalist.

31. See, e.g., Norman K. Denzin \& Yvonna S. Lincoln, The Sage Handbook of Qualitative Research (3d ed. 2005); Carl B. Klockars, The Professional Fence (1974); Robert K. Yin, Case Study Research: Design and Methods (2d ed. 1994). 
I am suspicious of any method said to be the one and only. But among the methods I would recommend is the intensive, penetrating look with an imagination as lively and as sociological as it can be made. One of my basic assumptions is that if one quite clearly sees something happen once, it is almost certain to have happened again and again. The burden of proof is on those who claim a thing once seen is an exception; if they look hard, they may find it everywhere, although with some interesting differences in each case. ${ }^{32}$

The story of Peter Lederer tells us many things about being a lawyer, about law firms, about globalization and cosmopolitanism, about lawyer-client relations, about careers, and even about legal education. The one thing that will become clear from the story is that none of these concepts are a finite thing. Each has an evolving and emergent characteristic that is sensitive to context. Indeed, we may say that this contextual sensitivity is crucial to succeeding in an inchoate and contingent world. Knowing the context, the situation, and the framing devices is essential to accomplishing good lawyering, for without this embodied knowledge one would blunder around. ${ }^{33}$

\section{A Note ON the U.S. Legal Profession}

A preliminary note on the state of the U.S. legal profession is essential to set the scene. New York has always been the commercial law center of the United States and home to its biggest law firms. ${ }^{34}$ The formation of the modern big law firm occurred in the late nineteenth century, almost coterminous with Dean Langdell's revision of the law school curriculum at Harvard. Its architect was Paul Cravath, who developed the internal promotion system for associates that ensured continuing growth for law firms throughout the twentieth century. ${ }^{35}$ The combination of rigorous legal education and the "up or out" promotion system within law firms created a class of lawyers that was no longer entirely based on ascriptive values, but was based more on merit and competition within the constraints of the period. Nevertheless, law firm partnerships were collegial institutions as reflected in their adoption of "lockstep" remuneration. ${ }^{36}$

Until the second half of the twentieth century, American law firms were largely parochial, and did not become engaged in international practice until the establishment of such enterprises as the Eurodollar and Eurobond

32. Everett C. Hughes, The Sociological Eye: Selected Papers on Institutions AND RACE, at ix (1971).

33. Cf. ERving Goffman, The Presentation of Self in Everyday Life (1959) (noting that life is a series of performances that have to be learned and displayed in performance).

34. Marc Galanter \& ThOMAS Palay, TOURnament OF LAWYers: The TRANSFORMATION OF THE BIG LAW FIRM 20-22 (1991).

35. See generally RoBert T. Swaine, The Cravath Firm AND ITS Predecessors, 18191947 (1948) (explaining the evolution of the "Cravath System").

36. Robert W. Gordon, The American Legal Profession 1870-2000, in 3 THE Cambridge History of LaW in America: The Twentieth Century and After (1920- ), at 73 (Michael Grossberg \& Christopher Tomlins eds., 2008). 
markets. ${ }^{37}$ They were distinct from the large U.K. law firms that, because of their small domestic markets, were compelled to internationalize much sooner. ${ }^{38}$ There were some outliers in the U.S. legal market, however, such as Jones Day in Cleveland, Morrison \& Foerster in San Francisco, and Baker \& McKenzie in Chicago. Within this cadre of law firms, Baker \& McKenzie was, in many ways, the most unusual. ${ }^{39}$

Baker \& McKenzie was started with the explicit aim of being an international law firm. Russell Baker, the founder, had been inspired by the cosmopolitanism of his professors at the University of Chicago to think of the world in internationalist terms. ${ }^{40}$ During the 1940s, Baker realized that he could exploit certain American tax provisions designed to assist trade with Latin America. ${ }^{41}$ By arranging sales through various subsidiaries, U.S. companies could save tax on their profits. Baker marketed the provisions to his immediate clients then promoted them through speeches and articles. ${ }^{42}$ One result was that Baker \& McKenzie began its global spread in Latin America rather than Europe.

Baker's approach was different from other firms' ways of opening overseas offices. Instead of opening an office in a foreign city and staffing it with expatriate American lawyers, Baker decided to use local lawyers. As one Baker partner said: “'You can't clone U.S. lawyers all around the world."”43 Nevertheless, there was significant movement of partners as new offices were established in order to inculcate the firm's philosophy to new lawyers. For example, the China and Hong Kong offices received a number of lawyers from the United States, the United Kingdom, and Australia. ${ }^{44}$ The principle was that all lawyers would be part of a single partnership - although Baker seemed to be primus inter pares - and that democracy would be the guide. While democracy allowed partners to deliberate in equality, the determinants of partner compensation had to allow for differences in styles and types of working practices among lawyers. Thus the firm adopted a remuneration formula. ${ }^{45}$ This approach was different from that of most law firms in that it rejected lockstep in favor

37. See Carole Silver, Local Matters: Internationalizing Strategies for U.S. Law Firms, 14 IND. J. GLOBAL LEgAL STUD. 67, 74-77 (2007). Much has been written on this topic and it would be redundant to repeat it here. GALANTER \& PALAY, supra note 34, and Gordon, supra note 36, are the key historiographical sources for the modern U.S. legal profession.

38. See Silver, supra note 37, at 74-77.

39. See generally BAUMAN, supra note 22.

40. Id. at 11.

41. See id. at 24-26; David L. Gibson, Western Hemisphere Trade Corporations: Reconsidered, 9 WM. \& MARY L. REV. 205, 205 (1967) ("Sections 921 and 922 of the 1954 Internal Revenue Code provide for special tax advantages for domestic corporations doing business in Western Hemisphere countries. However, these advantages may be accompanied by certain pitfalls.”). Russell Baker became a navigator through the pitfalls and strenuously defended the policy against critics. See BAUMAN, supra note 22, at 24-26.

42. BAUMAN, supra note 22, at 32.

43. Id. at 44 (quoting Robert Cox).

44. Id. at $193-216$.

45. Id. at $47-50$. 
of a more entrepreneurial platform that most highly rewarded individual effort.

For the first two or three decades, Baker \& McKenzie, despite having opened over twenty offices throughout the world, was sufficiently small that its partners could meet and make decisions fairly easily. As the growth intensified, the partnership felt pressure more keenly. Firm growth remained important, but deciding how and when to open new offices caused friction. Some offices, such as the Australian ones in the 1980s and 1990s, needed to be subsidized to remain active. The strictures of the firm's renumeration formula potentially disallowed this kind of cross-subsidy. If subsidies mean a diminution in partners' compensation, then partners sought alternative means of expressing their displeasure. For example, in Australia where adverse economic activity had forced up costs, the Sydney and Melbourne offices received close to a $\$ 1$ million subsidy, but the management of those offices shifted to younger partners. ${ }^{46}$

Baker \& McKenzie is a behemoth among law firms, but not among all professional service firms. It started with a goal to be a global firm that would have collegiality at its heart. Collegiality embraces trust, which is a prime constituent of a collective, based on shared principles. As long as the partners could know each other, take account of others' cultural values, and be part of a known entity, partnership could be articulated as a value-laden concept. With the extraordinary growth of the firm, it had no choice but to become attached to principles of management while trying to remain enamored of partnership. Ultimately, a firm like Baker \& McKenzie becomes a set of interlocking networks, virtual arms-length relationships tied together by strategic goals. In sum, Baker \& McKenzie started with two divergent aims - to be a global law firm and to be a collegial partnership—aims difficult to conjoin.

\section{EARLY CAREER SKETCH}

Our story concerns the life of a lawyer who spent most of his career as a partner with Baker \& McKenzie. Peter Lederer became the seventeenth partner of the firm in 1959. We start with a brief biographical sketch to set the scene. He was born in Frankfurt in 1930 and grew up in Vienna. The Lederer family was compelled to leave Austria and go to the United States after the Anschluss in 1938. Peter attended college at the University of Chicago, where he graduated in two years. He then spent a few years working for the United World Federalists before joining the Army. When he left the Army, Peter applied to law school and entered the University of Chicago, which did not have a Jewish quota. ${ }^{47}$ Peter became Karl Llewellyn's student and then his research assistant. Peter worked on The

46. Id. at 99 .

47. See generally Eli Wald, The Rise and Fall of the WASP and Jewish Law Firms, 60 StAn. L. ReV. 1803 (2008). Peter had also applied to Yale, and to Indiana as a failsafe. He was accepted by both Yale and Chicago, but rejected by Indiana because he did not possess a full four-year college degree. 
Common Law Tradition with Llewellyn, ${ }^{48}$ which proved to be a formative influence.

After graduation, Peter became the experimental first student—or, in his words, a test-tube baby-for a new two-year program funded by the Ford Foundation to engender interest in foreign legal studies. He learned German law from Max Rheinstein ${ }^{49}$ and had courses with Soia Mentschikoff ${ }^{50}$ and Nicholas deB. Katzenbach. ${ }^{51}$ Through Rheinstein's contacts, Peter spent his second year at the University of Berne in Switzerland. During this period, Baker \& McKenzie asked Rheinstein for help locating a suitable candidate, i.e., an American lawyer trained in Swiss law. A year later, Peter joined the firm. Within two months of joining, Russell Baker asked Peter to open an office in Zurich. Within four months, Peter was made partner and left for Zurich.

Many companies from various countries began to use Switzerland as a base for establishing holding companies. These became the building blocks for Peter's networks of clients and associates. He was establishing a reputation as an involved counselor. In interviews, Peter reflected on that reputation and the experiences that led him to it.

"Here's an interesting aspect of counseling-at least for me. I don't suppose that I can think of a situation where it was ever of great moment to me whether corporation $\mathrm{X}$ paid $\mathrm{Y}$ dollars more or less in taxes. Or did or did not close this deal. But what mattered to me a great deal, always and consistently, were the people who were involved in the transactions. In terms of trying to be counselor, facilitator, navigator - that was the high importance I tended to place on transactions. I suppose I didn't care if [Company X] acquired the German company, but I cared that [the chairman] at least really understood what the seller's problems with the transaction were.

"I suppose I tended to form quite close relationships with clients-if I liked them. And I had a great luxury: if I didn’t like someone, somebody else in Baker \& McKenzie was prepared to work with them. I really got to choose the things I wanted to work on. It's a luxury that few possessed in the law firm world any time, and particularly today. It made me place significant value - once I learned the term — on what it means to be a trusted advisor. You gained the ability to do things for clients that you couldn't do, absent knowledge and a relationship with the people you were dealing with. It didn't translate into personal friendships, particularly; in fact, I pretty

48. See generally Karl N. Llewellyn, The Common Law Tradition: Deciding Appeals (1960). The book garnered much criticism, a significant amount of which is reviewed in Patrick J. Rohan, The Common Law Tradition: Situation Sense, Subjectivism or “Just-Result Jurisprudence”?, 32 FORDHAM L. REV. 51 (1963).

49. See generally Guide to the Max Rheinstein Papers 1869-1977, UNIV. CHI. LiB., http://www.lib.uchicago.edu/e/scrc/findingaids/view.php?eadid=ICU.SPCL.RHEINSTEIN (last visited Apr. 21, 2012).

50. See generally Soia Mentschikoff, UnIV. MiAmi ScH. L., http://www.law.miami.edu/ library/soia.php (last visited Apr. 21, 2012).

51. Mr. Katzenbach recently published a memoir about his government service. See Nicholas DeB. KatZenbach, SOME of It WAs Fun: Working With RFK AND LBJ (2008). 
studiously avoided much in the way of social exchange. My standard was very simple; I didn't spend any social time with people if I wouldn't have wanted to do so absent the client relationship."52

After five years in the Zurich office, Peter turned down a suggestion to head up the Tokyo office and chose New York as his future base. Around this time, Peter also was appointed to the firm's Executive Committee and thereafter became involved in managing the firm.

\section{CASE STUdies}

In this section, we focus on the central case studies of this paper. They involve the intensive roles of counselor and trusted advisor that were alluded to above. What is interesting about the cases is that, unlike much of modern lawyering, they were not so much about document assemblagethough documents play an important role-but about the construction of institutions that were to have their own independent existence. Since the creation of institutions revolves around finding ways to bring similar interests together to pursue common purposes, the arts of persuasion, analysis, and even rhetoric are crucial to delivering success. The two case studies concern the U.S. nuclear power industry's establishment of a selffunding insurance scheme, and the merger of Deloitte with Touche Ross into one of the biggest accounting firms in the world.

At this period, globalization was still in its infancy. The two case studies concern both domestic law and global aspects. Although the nuclear industry case study appears domestic, it contains aspects that show its global features. It is based on the work Peter undertook in Zurich, and the work done in that case study led to the second case study. Thus, there is a direct link that crosses geographical and legal boundaries. For example, Peter's use of the Swiss Verein structure to join the two accounting firms was one of its first uses in professional services outside of a civil law jurisdiction. In effect, it was a legal transplant. ${ }^{53}$ Moreover, in both cases, much of the thought behind the documentation derived from Peter's experience with companies in Zurich seeking solutions to unusual circumstances.

The prequel to our cases occurs in the late 1960s. When the Boeing 747 was introduced, airlines found their insurance premiums skyrocketing. A number of airlines from around the world started discussing the idea of setting up their own insurance company to self-insure. Peter, shortly after returning to New York, became counsel to the project. He worked on it intensively over the next two years, becoming knowledgeable about the

52. The interviews we cite were conducted between February and April 2008 with supplementary interviews in September 2011. There have been many unrecorded discussions between the authors since the initial interviews, which have been used to amplify or interpret parts of the narrative. These statements, verified by the authors, have been lightly edited by the Fordham Law Review.

53. See generally Alan WATSON, LEgal Transplants: AN ApProACH tO COMPARATIVE LAW (2d ed. 1993) (discussing how legal transplants develop law through their interaction with host systems). 
insurance world: "It was something so new. The airline captive was really one of the first industry insurance operations that was ever contemplated. There was no book on it." Although the insurance company never fully materialized, Peter, as a result of his work for the airlines, was asked to be counsel to a nuclear facility insurance project as a result.

\section{A. Nuclear Power Self-Insurance}

The Edison Electric Institute had asked a committee to review problems with nuclear property insurance. Harry Poth, a well-known New York utility lawyer and a friend of one of Peter's partners, was asked to serve on that committee. Peter explains how he came to be involved:

The Edison Electric Institute "felt [the nuclear property insurance] to be indecently expensive for something they viewed as having zero risk of loss. I won't editorialize on that. They were at the point where they wanted to really explore this in depth, and they were trying to figure out whom they might find as counsel for the project. Harry Poth ${ }^{54}$ remembered that the aviation industry had looked at something very similar, and the general counsel of the Air Transport Association of America was an old friend of his. So he called him up and asked, 'You guys went through something like this, whom would you use as counsel?' He got the answer, '[i]f you want somebody who really understands insurance inside and out, I'd go to Lord, Day \& Lord. On the other hand,' he said, 'we used Baker, and while they had to do a lot of learning about insurance, they really got into it, and they carried through and did a bang up job for us.' Harry said 'Thanks,' and went to Lord, Day \& Lord. To my everlasting gratitude, about two weeks into it, Lord, Day \& Lord discovered they had a conflict. They told Harry they were sorry, they couldn't do it.

"That then led to my going to work, in 1970, with a group of about a dozen utilities that were exploring the feasibility of setting up an industryowned insurance company. The goal was to serve those utilities that either had or were about to have nuclear power stations. The feasibility study stage of this was undertaken by Ebasco Services Limited, a consulting spinoff from the old Electric Bond and Share Company. It was a group of technical people from almost every field you could think of who were very well connected to the utilities. I did a few weeks' worth of work-some suggestions as to corporate structure, situs, and issues of insurance law that would need to be dealt with. Ebasco explored the economic feasibility of setting up such a company, in little more depth than saying it can be done and that we can do it. They presented this report to the utilities.

"The project had been heavily pushed by J. Harris Ward, 55 the chairman of Commonwealth Edison in Chicago; he had assigned his general counsel, a man named Hubert Nexon, ${ }^{56}$ to the project. Ward and the others who received the report didn't much like Ebasco's fairly summary conclusions,

54. Mr. Poth was a partner at Reid \& Priest in New York.

55. See, e.g., Personalities, TiME, Feb. 21, 1964, at 86.

56. See Kenan Heise, Ex-Edison Executive H.H. Nexon, CHI. TriB., May 2, 1990, at 13. 
and decided to call a meeting of potentially interested utilities in Chicago for further discussion. I was invited to the meeting, and was surprised to find when I arrived that I was the only 'outsider'; they had not invited Ebasco or anyone else that had worked on the study. This was a strange situation. The meeting was out at O'Hare, and lasted about six hours. There had to be thirty-five or forty utility representatives present. ${ }^{57}$ There was lengthy discussion and they decided they would restart and do their own feasibility project.

"They decided to set up a six- or seven-person steering committee headed by Hubert Nexon and asked me to serve as counsel to the group. I was enormously pleased — and more than a little surprised —at the way things had developed. Ebasco, of course, was bent out [of] shape beyond all belief. They had viewed themselves as 'owning' the project.

"With that started a really intense two-year project, at the end of which we wrote our first insurance policy: it was for $\$ 100$ million of coverage, with resources of $\$ 14$ million cash in hand and the promise of the thirteen members to put up fourteen times one year's premium, if required by losses. It was called Nuclear Mutual Limited, or NML. In 1980, a second company called Nuclear Electric Insurance Limited (NEIL) was set up, which covered broader risks. Some years ago, NML was liquidated into its younger sister company, and today NEIL insures every nuclear property risk in the United States and a number around the world. It has a surplus of nearly $\$ 5$ billion. It has been one of the single most successful things ever done in that field."

Although the work began as a domestic project, it was based in work done outside the United States to assist companies operating in foreign jurisdictions. While much of the work involved in the project was strategic planning, the legal aspect had a life of its own, and derived from Peter's work drafting the articles for the airline captive. Peter demonstrates how this occurred.

"I mentioned earlier that I was retained to work for the airlines to set up a captive insurance company. When it came time to draft articles to be used for [an airline captive insurance company], I was up in Connecticut working on it at my weekend place. I didn't have access to the library. But I had up there copies of Swiss materials I had worked on. One of them was a set of articles I had drafted for a joint venture. So I took those articles, and adapted them to what I thought was going to be needed for the airline company. While we formed the company, and it still exists today in Bermuda, we never used those articles. But then a couple of years later, time came to form the [nuclear] utility-owned insurance company. Again, I needed a set of articles. Since I had fine-tuned the airlines' articles for a group captive, and thought through some of the issues of a multi-party ownership situation, I pulled those out and fiddled with them some more,

57. In an aside, Peter remarked that "[a]n interesting minor sociological fact was that I was the only person in the room wearing a blue shirt; everybody else had a white shirt on. And no women. That was the utilities of the '70s." 
and then used those as the articles of incorporation pursuant to which Nuclear Mutual Limited was incorporated in Bermuda.”

The legal aspect also became independent of its creator, as Peter discovered: “The company was set up, but hadn't yet started writing insurance policies - because we hadn't yet reached the critical mass that had been agreed as the starting point. ... . [T] The Ebasco Consulting people had had their noses very much out of joint about not being selected to work on this. So they decided to set up a competing vehicle of their own, and offer that to the utilities as an alternative to what had been done by our group. In due course, the chap who had first gotten me involved in all this, Harry Poth of Reid \& Priest, turned up acting as counsel for [Ebasco's project]. Somebody sent me a copy of their offering circular, which included the articles of incorporation for their captive. I started reading through that and I said 'Christ, this looks familiar.' They had lifted huge pieces, just verbatim. Their venture went nowhere, and Nuclear Mutual Limited proceeded very successfully. With Nuclear Mutual Limited, Bermuda started the first of what became a huge and very successful business of industry-owned insurance companies. It put itself on the map for large captives, and that really was the birth of the insurance industry as it exists today."

Moreover, this type of "legal technology" endures: "There was a third, Oil Insurance Limited, a venture of the large oil companies. I was also briefly the counsel for that, but got conflicted out when they fired their CEO since I had acted for him. There are, today, literally hundreds and hundreds of such insurance companies in Bermuda. The funny thing is, I can still pick up sets of articles and find some wording which traces back to those old Swiss articles."

It is a function of cosmopolitanism that the borrowing and transplanting of legal concepts was not the problem it appeared to be for comparative lawyers. Being comfortable in more than one jurisdiction made the transfer seamless; it was a means of finding solutions to complex problems. Indeed, this early work enabled the enterprise to become international in its later life.

One of the crucial parts of the NML operation was to find a base for it in a jurisdiction that would not impose overly burdensome regulatory obstacles. Peter and his colleagues evaluated many domestic and foreign jurisdictions and then settled on Bermuda. During this phase, Peter was an integral part of the enterprise, somewhat more than its counsel; the NML board relied on his judgment.

"It was a combination of factors. One of the reasons we picked Bermuda was not sophisticated insurance regulation, it was a lack of insurance regulation. It was an unregulated industry. There were some laws on the books about insurance, but they didn't apply to things of this size and scope. Basically, we picked it because of a lack of regulation, a lack of taxation, it being an English language jurisdiction, decent communications, and a decent level of competence among legal professionals and bankers. And the top accounting firms were well established there. They seemed 
more stable and more familiar than the islands in the Caribbean. Again, though, the critical point was really the lack of a formal system of insurance regulation.

"I suppose from 1969 to the mid-70s, we probably used Bermuda for twenty-five to thirty clients of ours. Part of it is simply the efficiency aspect. You've done one, then you've done two. By the time you have done three or four, you really know the ins and outs of how to deal there. You've built up working relationships with the legal community, the bankers, the accountants, and the government. Then comes the most powerful of all things - corporate fashion: 'What, you don't have a Bermuda captive? Don't talk to me on the golf course.' That led to some gnashing of teeth in some other places. From Colorado to Hawaii, then later Indiana and Vermont, all of these states wanted to be known as the place to set up an insurance operation. Over time, a number of them were more or less successful in attracting companies that, for one reason or another, found it useful to be physically proximate to wherever their insureds were located. And a change in the tax law in the early 80 s gave a shot in the arm to a number of the U.S. locations." 58

Insuring nuclear power stations was considered a typical low risk-high impact situation until the Three Mile Island disaster occurred.59 The disaster brought in other utilities, which had originally stayed outside the new insurance structure: "We continued as General Counsel for NML, and were retained to work on the question of setting up a program to provide business interruption insurance. It was not clear initially whether that should be a separate program or insurance policy offered by NML, or whether a new company should be formed. Ultimately, we decided for a range of reasons - one being that there was still residual tension between the non-NML utilities and the NML utilities - we decided to do it as a separate company. That was formed and was called Nuclear Electric Insurance Limited, or NEIL ${ }^{60}$ for short. Then came a further development. Once NEIL existed, the Nuclear Regulatory Commission said to the nuclear utilities, 'As a condition of your license, you have to show that you are financially secure to operate a nuclear plant, and financially secure means purchasing all the insurance that is commercially available.' Thus you had, in effect, a regulatory command to all utilities to join NEIL. The resources needed were simply too large to be available from the pools at that time.

58. It probably goes without saying that taxation is one of the key variables in how transactions are structured and also where they are situated. Tax questions often drive global or international solutions to difficult domestic legal problems. See generally DOREEN McBarnet \& Christopher Whelan, Creative ACCOUnting And THE Cross-Eyed JAVELIN THROWER (1999) (discussing how legal devices are developed by professionals in transactions).

59. See Backgrounder on the Three Mile Island Accident, U.S. NucLEAR REG. COMmission, http://www.nrc.gov/reading-rm/doc-collections/fact-sheets/3mile-isle.html (last visited Apr. 21, 2012). See generally CHESTER A. ZAGASKI, JR., ENVIRONMENTAL RiSK AND INSURANCE (1992).

60. See NuCLEAR ElECTRIC INS. LiMITED, http://www.nmlneil.com/members/default. aspx (last visited Apr. 21, 2012). 
The same approach—promises to pay at least $\mathrm{X}$ times one year's premium which had worked, by good fortune, successfully for NML- that was the way that NEIL started business."

Being counsel to both NML and NEIL had benefits for both Peter and the law firm. It enabled him to bring the client and firm together in a strong relationship that benefited the firm's younger lawyers: "One obvious aspect, it was a wonderful training ground for good young lawyers whom I could get involved in this work. For a while at least, it was a fulltime involvement simply because the scope of the work was so large. What it brought to us for the first time-remember, I told you that what set Baker apart from other firms, besides its size, is that we tended not to be general counsel. Here was a very large enterprise where we were general counsel, and whether it was dispute resolution or insurance questions, securities law questions, regulatory questions, antitrust questions, the full range of issues came up in the context of the two companies. Including, what turned out to be more threatening than any nuclear accident looming, a tax case.”61

After Peter retired from Baker \& McKenzie, he joined the NML/NEIL board. Peter had also attempted to persuade the company to move into the "export" market and go global, but it had to handle the parochialism of American industry as well as distrust from foreigners. During this period, globalization did not exist in the form that we now understand it. In the nuclear utilities industry, there was often deep suspicion of foreigners on both sides of the ocean.

"I thought it was a wonderful export product. Not long after NML started, I had the visit in New York of a Mr. Van Gulck, the insurance manager of Electrobel, a large electric utility in Belgium that has a nuclear power station. He wanted to know if they could join NML. He had heard about it and thought it was a nifty thing to do. I told him that I sensed the mood of the people was much too parochial to think of it as a possibility . . . I said, 'Look, just in bringing them together for NML we had to convince Duke Power Company that Con Edison in New York did not leave dirty, oily rags lying around.' They were suspicious of each other, and I said the idea of insuring your risk, outside the United States - not only is it foreign (and these are people who have no foreign businesses, which is truly important)—but you are not regulated by the Nuclear Regulatory Commission, and they really believe that measure of regulation is what keeps them on their toes. Possibly, were you to set up a European mutual along the lines of what NML has done, then perhaps we could work out mutual reinsurance arrangements or some sort of collaboration.

"And Mr. Van Gulck set out to do just that. That resulted in the formation of a Belgian company called EMANI (European Mutual Association for Nuclear Insurance). ${ }^{62}$ It never quite did very much. I had been convinced at the beginning, convinced years later, and am convinced

61. The tax case was eventually settled for $\$ 30$ million on a $\$ 600$ million claim.

62. See EMANI, http://www.emani.be/ (last visited Apr. 21, 2012); Liability for Nuclear Damage, WORLD NUCLEAR Ass'N, http://www.world-nuclear.org/info/inf67.html (last visited Apr. 21, 2012). 
still today, that there are so few of these risks in the world that the sensible thing to do would be bring all of it together to share the risks. The basic concept is this: for risks such as these, the world's commercial insurance markets are not going to use profitability from insuring bicycles or automobiles (or wherever they make their money) to underwrite losses in the nuclear insurance industry - or any number of other specialized industries. What the insurers provide essentially, other than know-how and rating - which you can either build or buy-is financing. There is cheaper financing to be had than by buying insurance. I have given papers on this, I have written on it, I have preached it-but I haven't quite converted the world.

"My views as to proselytizing were shared by one of the executives from Marsh \& McLennan who was the account executive from Marsh on NML/NEIL, Alonzo Rand. He had started as a nuclear engineer on the Manhattan Project under Stagg Field in World War II, and went to work in the insurance field as a nuclear engineer. $\mathrm{Al}$ and I were convinced that the message had to be preached. We decided to approach the utilities around the world to see if they were interested in at least coming together to discuss this. We got permission from our respective masters that this was not an unwanted or undesirable thing to do. We wrote to the nuclear utilities in Korea, Japan, Canada, throughout Europe, the United Kingdom, and South Africa and asked, would you come together on a given date? The Central Electricity Generating Board was kind enough to say they would host it at their offices in London, and we put on a three-day seminar for interested utilities. In the event, it was only the people from Continental Europe who showed up, plus the U.K. utilities, plus a Finnish utility, and the South Africans. We did a good three-day seminar. The long and the short of it was this: everybody was very interested, thought it was a great idea, but nobody was prepared to really get behind it and push. EMANI, in the meantime, was limping along, slowly gathering members. What they had done was to ride piggy-back on the European pools' insurance policies. You do everything, you issue the policy, but we will only write two percent of the risk. It was so small, actually, as to be meaningless. They were not prepared to commit either present capital or in the form of promises. Without that they were going nowhere.

"NEIL then having, in due course, conquered the U.S.- - the commercial insurance pool still exists but it is virtually irrelevant by now-with much nudging on my part then took a look at a couple of European risks, and several utility prospects seemed to be interested. After a great deal of gentle persuasion, the board kind of reluctantly said, 'You can talk to the people in Spain who are particularly interested.' And there was some interest shown by the Swiss utilities - I had generated a part of it because I was involved with them in Switzerland. It was decided to set up a subsidiary of NEIL in Europe and put somebody over on its staff to work the European market. That was set up in Dublin, and since people are cute, it was named O’NEIL for Overseas Nuclear Electric Insurance Ltd. 
"The end result was that NEIL got a new member, Electrabel. ${ }^{63}$ Electrabel had been purchased by Suez, and was a bit more internationalminded than they had been in the past. We had our first non-U.S. utility and first European board member."

Clearly parts of corporate America were slow to capitalize on the growth of globalization occurring during this period, but few of the global institutions that ease the path of commerce, such as the International Swaps and Derivatives Association, existed at this time, so the approach to risk management was cautious and slow. Cosmopolitans such as Peter were a rarity and were only beginning to flex their comparative and international muscles. Every aspect of globalization had to be built from the ground up. The result was that institutional failure was as much a part of the process as success. In the case of nuclear power insurance, it was not a global success despite the regard, as advisor, in which the industry held Peter. The role of lawyers like Peter was to create the circumstances that would encourage different groups to entertain the realistic idea of working together. It was to create and foster a community of interests. It was slow and painstaking work that did not always reach its goal.

\section{B. The Accounting Business}

The second case study involves the accounting business. Overlapping with the work on the nuclear industry, which involved attempting to bring together disparate groups in a common enterprise, Peter began to work for a number of international accounting firms on organizational and structural matters. He worked on setting up a new structure for Grant Thornton, ${ }^{64}$ then a Chicago-based accounting firm that had decided to go global. That led to a colleague from the former airline captive insurance project asking Peter to talk to the general counsel of Touche Ross. ${ }^{65}$

"He was wrestling with what to do with Touche Ross International which, when first encountered, was simply an agreement amongst the international firms. It was not a very good one, and it was coupled with a name-holding partnership that they had set up in the Bahamas-as to which nobody seemed to know exactly how it might work or what it did. So after a good deal of work, that led, for the first time, to the idea of exploring a Swiss Verein as the vehicle."

Again we see the resurgence of Peter's Swiss roots as a lawyer in his selection of this particular vehicle to solve Touche Ross's international partnership problems. At this time, Touche Ross was an amalgamation of

63. See About Us, ELECTRABEL, http://www.electrabel.com/whoarewe/whoarewe.aspx (last visited Apr. 21, 2012).

64. See History of Grant Thornton LLP, GRANT THORNTON, http://www.grantthornton.com/ (follow “About us” hyperlink; then follow "History of Grant Thornton” hyperlink) (last visited Apr. 21, 2012).

65. See Family Tree, ICAEW, http://www.icaew.com/en/library/subject-gateways/ accounting-history/resources/whats-in-a-name/touche-ross (last visited Apr. 21, 2012). 
fifty U.S. firms and firms from fifty-five other countries. ${ }^{66}$ Given this level of complexity, it is unlikely that a purely U.S.-trained lawyer would have arrived at an equivalent solution, not having experienced overseas work.

"An interesting aspect of the Verein is that it had been used for limited commercial purposes. A Verein under Swiss law is not permitted to engage in a commercial activity, but the Swiss Supreme Court had held, in the 'Cigarette Cartel' case, ${ }^{67}$ that even though the Verein's members had a commercial activity, they could use the form of the Verein to come together to govern the relations amongst themselves. That was not to be considered commercial activity. Second, of importance to Touche Ross, and ultimately to a number of other firms that were considering similar structures, a Verein could be a coming together of entities. It did not need to have individual members of the Verein, but firms could be the Verein's members. Indeed, individuals could not be members of the Verein. Third, it was a democratic form of institution, with governing bodies that you could pretty much tailor to your taste. Finally, though really never tested, the liability of members of the Verein, for claims against the Verein itself, was limited to the amount of their contributions to the Verein. It thus provided an extremely interesting legal form, at least one major bulwark against vicarious liability. So using a Verein was ultimately agreed to, we worked on it, we set it up. Then, Ernst \& Ernst retained me to work on their coming together with Whinney Murray - this is now taking me from the 1970s to the early 80s.”

At this stage, Peter's reputation as an institution creator and troubleshooter had grown extensively. Companies and professional service firms with complex and complicated international structures that were no longer sufficient for modern global commercial demands were desperate to find ways to restructure themselves that would fit with more convergent and coherent ways of doing business. In the period from the 1960s to around 1980, gross world product and foreign domestic investment flows doubled in size. ${ }^{68}$ More countries were becoming involved in the General Agreement on Tariffs and Trade, there was more openness, and exports rose dramatically. 69

For Peter, this was an exciting era and he was becoming an industry specialist. His reputation, allied with the growth of Baker \& McKenzie into the world's largest law firm, gave him a solid base. Both Touche Ross and Ernst \& Ernst, as well as KPMG (another of Peter's clients), became members of the Big Four accounting world group.

"I did get known as the lawyer who understood how accounting firms work. Ernst \& Ernst was, at first, concerned that anything I did for them should be proprietary. They didn't want all this valuable information shared with any of their other seven, as it then was, competitors. I said I

66. See History, DELoITTE, http://www.deloitte.com/view/en_GX/global/about/ overview/history/index.htm (last visited Apr. 21, 2012).

67. Bundesgericht [BGer] [Federal Supreme Court] Feb. 11, 1936, 62 ENTSCHEIDUNGEN DES SCHWEIZERISCHEN BUNDESGERICHTS [BGE] II 32 (Switz.).

68. HelD ET AL., supra note 16, at 242 tbl.5.1.

69. Id. at $164-65,169$. 
couldn't do that. That, obviously, they benefited from the work I had done with other firms. I certainly accepted the obligation not to tell anything about their internal business affairs to anybody else, but the concepts couldn't be proprietary. Interestingly enough, not only did they buy that, but in not one of the relationships I had with any of the accounting firms was there any significant objection to the fact that I had acted for everybody else.”

Peter's role as a senior partner involved in management at Baker \& McKenzie helped because of the similarities between the law firm and the accounting clients. The ethos of the professional services firm was not too dissimilar across disciplinary boundaries. Their structures shared common problems and, since both Baker \& McKenzie and the big accounting firms were global institutions, Peter's experience was invaluable. If he had been a U.S. law firm partner, he would not have been able to appreciate the cross-border difficulties that arose in his work. It is in this kind of work that the synergy between Peter the Individual, and Peter the Partner at Baker \& McKenzie is actively demonstrated.

"At the start of this work [with the accounting firms] I was on my second tour serving on the Baker \& McKenzie Executive Committee. So that was a level of Baker \& McKenzie management I think they felt I had seen intimately enough to know what the issues were and how they were dealt with. There was also the fact that in dealing with the international governing bodies of the accounting firms, as I tended to do as these projects went forward, these people knew their counterparts in the Baker \& McKenzie offices-in Mexico or Italy or in New York. They might often compete with us, incidentally, because . . . KPMG competed sharply with law firms, but at least they knew my people. That was unquestionably a plus as well. I could, for example, say-if there were something under Italian law the representative of the Italian firm worried about, in terms of participating in a recommended structure-I could tell him to go talk it over with Alberto DeLibero, the senior partner of the Milan office. He was highly regarded as an objective sort of guy. That was very helpful, obviously. The counterpart of it, in terms of difficulty, was that there was occasional unhappiness on the part of some of my partners in the firmhaving a special relationship for a period of time, let's say with Ernst \& Ernst, when they were trying to foster something with Arthur Andersen. ${ }^{70}$

I worked on Ernst \& Ernst's merger with Whinney Murray [in 1979]. Then came KPMG. They had a general counsel in the United States, Victor Earl. I forget how I met Vic; I had met him a couple of times and we sort of bristled at each other-I can't even remember why. I got a call from him though, and he asked if I could come over to talk to him. The story he told me was that they had expanded very rapidly in terms of offices in Latin America. There were difficulties in building up his in-house legal staff with

70. The role of conflicts of interest in law firm development has been one of the prime reasons for the establishment of the law firm general counsel. See generally Elizabeth Chambliss, The Professionalization of Law Firm In-House Counsel, 84 N.C. L. REv. 1515 (2006). 
rapidity, and he asked if I would act as general counsel for his Latin American group of offices with any legal issues, questions, and problems they had. I think he had seen my work product somewhere and liked it. It was a nice offer, and we talked it through and I thought it over and accepted it. Regretfully, in terms of work, within the year, they had decided to merge with Peat Marwick so that was the end of that engagement. Then I was consulted around the fringes of Arthur Andersen's restructuring."

In 1989, the accounting mergers, well in advance of law firm mergers, began in earnest. ${ }^{71}$ Peter had now acted for four of the largest accounting firms in the world and was regarded as the industry restructuring expert who understood global mergers.

"Then the Deloitte ${ }^{72}$ thing really started when I had a call from Touche Ross's general counsel, Rick Murray, ${ }^{73}$ saying that while it was still totally confidential, it looked to be the case that Touche and Deloitte were in very serious merger talks. He asked whether I would act as counsel/resource to the Touche Ross member firms around the world in addressing the legal issues they had in coming together with Deloitte. That led to my communicating with all the firm's offices asking each of them to designate a contact partner whose name could be made available to the local Touche Ross firm. I asked them to hold themselves available, and be sure to keep me informed of what transpired-if anything. I told them I would do centralized billing and told them what I knew of some of the issues going on and outlined the proposed structure and deal.”

As is often the case with complex matters of this sort, little was straightforward: "So, I got that all set up - and very little happened. The Frankfurt office got a call on something, the Mexico City office got a call on something, but two or three months went by with quite a low level of activity. Then I got a call again from Rick Murray, who apologized. He said that he had been zipping all around the world. He had come to realize that the problem was really to figure out how to bring the two international organizations together, and that obviously, since he was the counsel for one party, he himself could not fulfill that role very well. He wondered whether I would undertake the job of serving as counsel to both sides on the legal issues of putting themselves together. I said I didn't know. I knew Rick and I knew Tom Presby (who had introduced us), ${ }^{74}$ but I did not know the head of Touche Ross. And as far as Deloitte was concerned, I didn't know their people at all. I told him that before saying yea or nay, I would like to meet them. He said that was totally reasonable, and that he would set up an

71. See generally Mun Soo Choi \& Daniel Zéghal, The Effect of Accounting Firm Mergers on International Markets for Accounting Services, 8 J. INT'L AcCT. AUDITING \& TAX’N 1 (1999).

72. See About Deloitte, DELOITTE, http://www.deloitte.com/view/en_US/us/About/ index.htm (last visited Apr. 21, 2012).

73. See Richard Murray, REPUTABILITY, http://www.reputability.co.uk/section.php/61/1/ richard_murray (last visited Apr. 21, 2012).

74. See J. Thomas Presby, FORBES, http://people.forbes.com/profile/j-thomas-presby/ 4628 (last visited Apr. 21, 2012). 
appointment for me to meet with Ed Kangas $^{75}$ and Mike Cook, ${ }^{76}$ the respective managing partners of Touche and Deloitte. He told me I should also meet a man named Bob Buesser, ${ }^{77}$ who was intended to be the Chief Operating Officer of the combined firms.

"I arranged to go over to their offices one morning. Rick took me into a meeting that was in progress, where Ed Kangas and Bob Buesser were present. Mike Cook, I was told, intended to come, but wasn't quite sure if he could make it. But why didn't we start? So the three of them and I sat around for an hour or so, discussing in broad outline what was involved in bringing two international firms under one roof-and where that roof might be. After an hour or so I noticed, subliminally, that Rick Murray had walked out, and that was the last we saw of him at the meeting. Somewhere around five that afternoon I was still sitting there, and we were still talking about the mechanics of how you do this, and what the issues were, and Ed Kangas - as we were about to adjourn for the day_asked, 'You're going to work on this?' I said, 'I guess I am.' There had been excellent rapport and the fullest of conversations.

"With that started an intense period of work over a couple of years. The two dominant firms-Touche Ross United States and Deloitte, Plender, Haskins \& Sells United States-had agreed that they wanted to merge. Both had the support, with some variations of enthusiasm, of their other top three or four member firms around the world. Those basically tended to be the Anglo firms - Canada, Australia, U.K.- - with, I think it probably fair to say, less enthusiasm on the part of the rest of the world. I think that was really for two reasons. In the accounting profession, the Anglo-American firms historically had been the dominant ones for well over a century, and they felt a natural affinity: their training was similar, their roots were all in Scotland somewhere, and they came most easily to the view that they would do well by having a closer union if they got together. But a large number of issues needed to be resolved. In each country, you had the task of putting together two firms that had different styles and different cultures. Touche was probably in some ways, in many places, looked upon as a younger and brasher firm than was Deloitte-that was an older and more settled firm. Whether that comported with reality is a different issue, but at least that was the perception. Or, in a given jurisdiction, one firm might view itself as more powerful, more successful, the better firm. There ensued a series of negotiations, literally around the world, in terms of people trying to decide: would they or would they not be willing to get married. As the head of one firm said to me, 'You know, the situation we face is that it is an arranged

75. See Edward A. Kangas, DeloitTe, http://www.deloitte.com/view/en_US/us/About/ History/Leaders-Shapers/74e15264b03fb110VgnVCM100000ba42f00aRCRD.htm (last visited Apr. 21, 2012).

76. See J. Michael Cook, DeloitTE, http://www.deloitte.com/view/en_US/us/About/ History/Leaders-Shapers/58dfad9fed2fb110VgnVCM100000ba42f00aRCRD.htm (last visited Apr. 21, 2012).

77. See Haskins \& Sells/Deloitte, Plender, Haskins \& Sells, New Partners and PRINCIPALS 4, 6 (1969), available at http://clio.lib.olemiss.edu/cdm4/document.php? CISOROOT=/deloitte $\&$ CISOPTR=49427\&REC $=5$. 
marriage. The parents on both sides think it is a wonderful thing, but we've never met the girl.'

"The legal job was multipart and interesting. One key issue was where, and how, are we going to put the structure together. As I told you before, it wasn't an automatic assumption; we went back and looked to see what alternatives were available, what other international firms were doing, had there been any changes in the law anywhere that made country A or B better or worse. We did wind up once again saying that we thought that a Swiss Verein was the best solution. One significant aspect of the choice was that the Touche side had worked happily for ten years with that structure. That sharply reduced the sales job, plus it gave the Deloitte people somebody to talk to. 'So how does that work for you?' Answers independent of what the lawyers had to say about it. So that was number one.

"A second was also interesting; there were antitrust issues that came up sharply, in the United States and in the EU. In the United States, that was handled by Skadden Arps, who was acting for the two firms on the U.S. merger issues - they also needed SEC approval for everything. By then the number of accounting firms was really starting to shrink and there were serious concerns. We handled the EU part of the antitrust issues. A very good antitrust expert in Baker's London office, Linda Martin, ${ }^{78}$ worked on coordinating that; she worked closely with the U.K. Deloitte and Touche firms, did the Brussels part of it with some people out of our Brussels office, and got a satisfactory solution. Not easy to get, but got it done within a decent time.

"I was doing two primary things: one was staying on top of coordinating the whole range of work that was being done. Then, on a handful of occasions, I was trying to use my good offices-firms were bumping into intractable issues in bringing themselves together. There were perhaps four or five partners from either Touche or Deloitte's international operation offices (both firms had large international structures before the merger) and the best people were taken from each of the two groups to be the troubleshooters around the world. I joined that group and went off to try to help facilitate the marriage of the two German firms that didn't want to marry, and there were also the Turkish firms that didn't want to. Turkey in particular was interesting. The first Iraq War had just started. You could fly from New York to Turkey on the Turkish airline-but I didn't want to. So I flew on Swissair to Zurich and from Zurich down to Istanbul. Swissair at the time still flew 747s - but people were nervous and there were only twelve passengers on the plane!

"The next day, Saturday, we met in the Touche offices and we started early. We reached an agreement-except three months later the agreement had come apart. So I met with them again, they flew to Brussels where I met with them, but they could never get together.

78. See Linda Martin Alegi Biography, ABA, http://apps.americanbar.org/antitrust/atbios/alegi-lynda.pdf (last visited Apr. 21, 2012). 
"While all of this is going on, we get the Verein formed. I have in the meantime assembled a home court team in New York, basically one younger partner and two associates. We start doing the documentation, and prepare something along the lines of an offering circular that we can send around the world. We get it blessed by the various people that need to bless it and send it out. Then there started feeding in - at first kind of a trickle and then a very steady stream — of 'I've got questions about this or . . . I've got questions about that.' In a number of cases, we got the people from a local [Baker] office involved - to speak the same language as the question askers. We started the formation process in Switzerland, and then began the sign-up process. The two major firms had agreed they would announce the Verein's existence when we reached critical mass of a given number of firms having signed on to it. In the space of about a year, we were off and on our way.

"There was an international Executive Committee established for the Verein. That committee consisted initially of some twelve or thirteen people; the heads of seven or eight of the largest firms, and then a scattering for either geographical representation or small firm participation. And here again, I started meeting with that Executive Committee. I did not do this for as long as I had in NEIL's case; I did it for probably the first two years of the group's existence-by that time, the issues had been pretty well ironed out. But by that time I had told Ed Kangas . . . I started thinking about how much time I was spending on this . . it was a hugely absorbing thing, I was then in my early sixties, and I was still extremely heavily involved with NML and NEIL, and I decided I really needed to try to simplify existence a little bit."

As the Deloitte-Touche merger came to fruition, Peter found himself being asked to undertake the strategy work for the new combined firm. ${ }^{79}$ The result was that Peter formally resigned from Baker \& McKenzie and became Of Counsel, but continued to work on strategy for them, NEIL, and Deloitte \& Touche. By this time, Peter had become the focal point of the restructuring work of the various companies and firms. Not only was his role to formulate the structures, but it extended into ensuring they survived and became established so they could take on their own independent existences.

\section{DISCUSSION AND CONCLUSION}

In this Article, we have tried to demonstrate how cosmopolitanism and globalization are connected through the medium of a lawyer's practice. Our particular emic approach has permitted us to view a lawyer's work, client relationships, and law firm participation through the use of thick

79. One of Peter's last tasks at the firm was to chair the Nominating Committee that sought potential members of the firm's governing committees. He was instrumental in persuading a young female partner in the Paris office to join the Executive Committee. That young partner was Christine Lagarde, who went on to head the firm in 1999 and is now head of the International Monetary Fund. 
description. ${ }^{80}$ Contemporary scholarship suggests that globalization is a more recent phenomenon than cosmopolitanism, which has an extensive history. They are connected but not isomorphic. Taking the history of cosmopolitanism, we can see how it gave rise to globalization as a mode of discourse about the world. Cosmopolitanism and globalization reflect a deep involvement with the world and its cultures: they envisage sensibilities that appreciate and celebrate difference. By contrast, internationalism is flatter and less textured in that it concerns the relations between states rather than cosmopolitan incursion into cultures and sentiments. ${ }^{81}$ Cosmopolitanism, especially as articulated in terms of Held's eight principles, ${ }^{82}$ is contextual and involves agency.

Peter's career, of which a small part has been shown here, is emblematic of the notion of a cosmopolitan that Appiah puts forward from the Cynicsthat the cosmopolitan is a citizen of the cosmos who perturbs by being skeptical of convention, and by being one who challenges orthodoxy. Therefore, the role of the cosmopolitan is to challenge, yet persuade, and include that which can be perceived as part of the republican ideal. It endorses inclusiveness and community, yet does not disregard difference.

When we examine what Peter was doing in connection with both the nuclear industry and the global accounting business, we see this concept in practice. Peter's role was to assist in integrating disparate cultures into a cohesive entity that would take on a life of its own. He achieved this, at the most mundane level, by mixing together different legal cultures, especially introducing the Swiss Verein into corporate life. But at a more subtle level of complexity, Peter brought about a refocusing of the institutions in play from being atomized elements to becoming powerful cohesive organizations with global reach. The discourse of differences had to be reconstituted into a conversation of commonality. It is not something achieved overnight. At first, it takes continuing negotiation and suasion to bring the different groups into a common understanding. Then, it takes monitoring and reviewing to ensure that fission does not occur, as we saw with Peter's own continuing involvement with the organizations he helped establish.

In order to bring about these accomplishments successfully, Peter had to demonstrate his knowledge of, and sensibility to, different legal systems,

80. See generally ClifFORD GEeRTZ, The InTERPRETATION OF CULtURE (1973). Geertz borrowed the term "thick description” from Gilbert Ryle. See Gilbert Ryle, The Thinking of Thoughts: What Is 'Le Penseur' Doing? (Univ. Saskatchewan, Univ. Lecture Series No. 18) (1968), available at http://lucy.ukc.ac.uk/CSACSIA/Vol14/Papers/ryle_1.html. Ryle analyzed two boys moving their eyelids, which could be an intentional wink or an involuntary twitch of the eyelid. A third boy then parodied the first boy's wink. See id. Geertz believed we are suspended in webs of significance and that the role of thick description is to disentangle those webs so that we may fully understand the significance of action and symbols. See generally GEERTZ, supra.

81. See generally Michael W. Doyle, Liberal Internationalism: Peace, War and Democracy, NoBEL PRIzE, http://www.nobelprize.org/nobel_prizes/peace/articles/doyle/ (last visited Apr. 21, 2012) (observing that cosmopolitanism argues for accommodation and consensus within states, as well as across borders, and therefore avoids conflict and war).

82. See supra note 13 and accompanying text. 
different cultures, different societies, and different languages (geographic and professional), to reconcile the elements revolving in this socio-culturallegal space. We say "socio-cultural-legal” because we are trying to capture something more than merely the legal aspect. If Peter had no comprehension of the things mentioned, his task would have proved impossible. This is not to say that Peter was unique, but he was part of a small cadre of lawyers who were able to undertake these kinds of roles. They were lawyers who explicitly resisted being technocrats. Theirs was not the minutiae of the contract clause, but rather the conception of what the contract was trying to achieve and more.

Moreover, there is an additive quality to this conception. Peter had to demonstrate authority as well as sensibility in order to command a persuasive role. It certainly came from his skill in law, but also in his capacity to tap into resources that would augment and reinforce his skill. The global law firm provided the infrastructure of his authoritysomewhere in the world there would be a source of expertise on hand to supply answers. In addition to the authority of expertise, Peter introduced an authority that derived from his position in the law firm, that of an experienced and senior partner, one who was deeply involved in the management of the firm. His clients, most of whom were senior members of their organizations, would acknowledge and understand his status, and find assurance in it. These displays of authority, not explicit and overt, helped create the persona of the trusted advisor. Peter's position shaped the possibility and probability of assured reliance, and diminished and managed the potential for risk on which these clients' enterprises were built.

The emergence of new professional groups in the last forty years or so has affected the position and development of cosmopolitan lawyers and advisors. Indeed, it may have attenuated their influence. For example, management consultants and big accounting firms have assumed some of these roles and are involved in the creation of new regulatory structures. ${ }^{83}$ Lawyers are retreating to a more technocratic role focused more on the construction and composition of documentation. If this is true, where does this leave the cosmopolitan lawyer as we have portrayed him? He is not bereft nor has he disappeared; he has assumed a new identity.

We close on the reason why we began this project. It is because we see value in the ideal of the cosmopolitan lawyer. Cosmopolitanism is a source of good in a world riven by cultural misunderstanding. The rule of law and those who convey it need to be able to function in the world. There is a need for translators and interpreters at a cultural level, who go beyond the trite. Law firms may no longer be the most appropriate vehicles for imparting this knowledge. Having now abandoned the central value of the

83. See Julia Black, The Development of Risk Based Regulation in Financial Services: Canada, the UK and Australia, ESRC CENTRE FOR ANALYSIS RISK \& REg., LONDON SCH. ECON. (Sept. 2004), http://w.lse.ac.uk/collections/law/staff\%20publications\%20full\%20text/ black/risk\%20based\%20regulation\%20in\%20financial\%20services.pdf (discussing the different approaches to risk-based regulation taken by three financial regulators, though none have successfully achieved a robust measure). 
Cravath system - the training — they are more attuned to mass production. ${ }^{84}$ If this is the case, then imparting these ideals has to take place elsewhere.

In Peter's case, he has already made the shift. He was instrumental in creating and developing a new legal education venture that would attempt to embody the values of cosmopolitanism and globalization. LawWithoutWalls, based, but not exclusively, at the University of Miami School of Law, has entered its second year with twelve law schools situated across nineteen time zones. ${ }^{85}$ For one semester each year, groups of students are exposed to an interdisciplinary mix of lawyers, entrepreneurs, social scientists, pedagogical techniques, technological innovations, and conversations that attempt to inculcate the ideals we have been describing in this Article. We hope this is the rebirth of the cosmopolitan lawyer in a global setting.

84. See, e.g., Robert A. BroOKs, Cheaper by the Hour: Temporary LaWyers and THE DEPROFESSIONALIZATION OF THE LAW (2011) (analyzing the rise of the contract attorney in the legal profession and the deprofessionalization of legal work).

85. See About, LAWWITHOUTWALLS, http://www.lawwithoutwalls.org/about/ (last visited Apr. 21, 2012). 